\title{
The Persistence of Union Membership within the Coalfields of Britain
}

\author{
Huw Beynon $^{1} \quad$ Helen Blakely ${ }^{1} \quad$ Alex Bryson ${ }^{2}$ () $\quad$ Rhys Davies ${ }^{1}$ (1)
}

${ }^{1}$ Cardiff University

${ }^{2}$ University College London

\section{Correspondence}

Rhys Davies, Wales Institute for Social and Economic Research and Data (WISERD), Cardiff University, Cardiff, United Kingdom of Great Britain and Northern Ireland.

Email:DaviesOR@cardiff.ac.uk

Final version accepted on 18 December 2020.

\section{Funding information}

Economic and Social Research Council, Grant/Award Number: ES/S012435/1

\begin{abstract}
Spatial variance in union membership has been attributed to the favourable attitudes that persist in areas with an historical legacy of trade unionism. Within the United Kingdom, villages and towns located in areas once dominated by coalmining remain among the strongest and most durable bases for the trade union movement. This article empirically examines the effect of living within or near these areas upon union membership. Those residing in ex-mining areas retain an increased propensity for union membership. However, this effect diminishes sharply with distance. The analysis reveals that particular places can serve as conduits of trade unionism, long after employment within traditional industries has vanished.
\end{abstract}

\section{1 | INTRODUCTION}

The long-term downward trend in union membership in the United Kingdom is well known. Based upon membership returns submitted annually by individual trade unions to the Certification Office, trade union membership within the United Kingdom peaked in 1979 at approximately 13.2 million. Since then, there has been a precipitous decline, such that there are now around 6.8 million members. Estimates published by the UK Government based upon data from the Labour Force Survey (LFS) also places current union membership at approximately 6.8 million. Between 1995 and 2019, the percentage of employees who were trade union members (referred to as 'union density') declined from 32 to 24 per cent (BEIS, 2020). Official estimates for 2019 however reveal the persistence of regional variance in union membership across the United Kingdom. Union density in England ranges from 18 per cent in London and the South East to approximately 28-29 per cent across the regions of Northern England. Among the devolved nations, density is estimated to be 29 per cent in Scotland, 31 per cent in Wales and 34 per cent in Northern 
Ireland. Given the potential benefits of union membership to employees (Bryson \& Forth, 2017) and its implications for productivity and workplace performance, it is important to understand the factors that underpin such differences in union density across different parts of the United Kingdom.

A number of studies have examined how much of the decline in union membership observed over recent decades can be attributed to compositional changes in the structure of employment and, by inference, how much can be attributed to changes in the propensity of workers to join unions (Blanchflower \& Bryson, 2009; Bryson \& Gomez, 2005; Green, 1992). Less attention has however been given to understanding the persistence of spatial variance in union membership. Early patterns of union membership were largely attributed to the geographical distribution of employment within industries characterized by relatively high levels of organized labour (Phelps Brown, 1959). However, even at the height of trade union membership within the United Kingdom, both individual and establishment level studies identified the presence of significant regional effects (Bain \& Elias, 1985; Beaumont \& Harris, 1988; Elsheikh \& Bain, 1980), with levels of union membership and coverage higher within Wales, Scotland and Northern England than would otherwise be expected. Martin et al. (1996) demonstrate that these regional effects persisted during the 1980s despite the substantial deindustrialization and economic restructuring that occurred within these areas (MacKay \& Davies, 2012). The perseverance of such patterns is confirmed in subsequent studies by Monastiriotis (2007) and Beynon et al. (2012). Geographical variations in unionization have endured despite the general tendency for regional differences in employment structure to diminish.

In explaining why structural effects are unable to account for geographical variance in union membership, Martin et al. (1996) emphasize the importance of 'regional and local variations in the inherited and socialised traditions, customs and cultures' (p. 99) that influence both the propensity of individuals to join unions, the attitudes of employers towards unions in the workplace and the nature of trade union practice. The inference being made from these empirical analyses is that within areas once characterized by employment in highly unionized sectors of the economy such as mining, steel, ship building and manufacturing, geographically based traditions continue to underpin spatial subsystems of trade unionism and industrial relations (Dunlop 1958). Beaumont and Harris (1988) therefore suggest that broad administrative areas (or aggregations thereof), with their sharply defined borders, are not the most applicable spatial unit of analysis to empirically identify the importance of historical and cultural factors influencing union membership within the contemporary period. Variation in such phenomena is more appropriately examined at a sub-regional level of analysis (Beaumont \& Harris, 1988: 400).

Within the United Kingdom, colliery villages and towns located in areas once dominated by coalmining remain among the strongest and most durable bases for the trade union movement (Beynon, 2014). However, the direct influence of living within a former coalmining area upon union membership within the United Kingdom has been largely ignored. This article examines the union joining behaviour of those who reside either within or near to areas that were once dominated by employment in mining, utilizing data from the LFS from 2000 to 2018. ${ }^{1}$ Analysis reveals that those residing in areas where there is an historical legacy of coalmining still exhibit an increased propensity to join trade unions compared to neighbouring areas. The analysis demonstrates the importance of locality, history and the associated culturally embedded values which endure over time for our understanding of contemporary union membership. 


\section{2 | FAMILIES, LOCALITIES AND THE PATH DEPENDENCE OF UNION MEMBERSHIP}

Within areas where there is an historical legacy of trade unionism, the propensity of workers to join trade unions appears to be greater due to the favourable attitudes that exist towards union membership (Charlwood, 2002; Diamond \& Freeman, 2002). Holmes (2006) provides evidence as to the importance of such processes to the persistence of union membership in the United States. Statistical analysis of establishment level data demonstrates that higher unionization rates in care homes and grocery stores in West Virginia and Pennsylvania are linked to the unionization of the old coal and steel sectors in those areas. The analysis directly reveals how historical proximity to once highly unionized workplaces spills over to the present day, to other groups of workers and firms, including those in relatively unorganized sectors. Although the specific mechanisms involved are complex and are themselves influenced by the process and path of economic development, the result is that the attitudes, expectations and behaviour of employees and employers in other industries in the region are influenced by the historical traditions and contemporary proximity to these locally dominant industries and their workforces (Martin et al., 1996: 118-19).

Earlier research also afforded great significance to the social environment of workers beyond the workplace in explaining attitudes towards union membership (see, for example Goldthorpe et al. 1969 and Bulmer, 1975). In Marshall's (1967) classic study of labour in the South of the United States, the success of a strike by female garment workers in the late thirties in Tennessee is explained in part by the family connections of the strikers, many of whom had brothers and fathers who were members of the United Mine Workers Union. A study by Beynon (1973) of union formation within a new plant of the Ford Motor Company in Liverpool considered the 'roots of activism' and explored the reasons why those men recruited as assembly line workers became trade union activists. In this account, the influence of kinship emerges as a significant factor, providing workers new to the assembly line with a 'trade union interpretation' of particular events within the workplace. These studies demonstrate that personal connections embedded in localities can endure as conduits of trade unionism and collective forms of consciousness.

Within economics, two related explanations for the persistence of geographical variations in union membership have emerged. Booth's (1985) 'social custom' model of union membership contends that in an area characterized by favourable attitudes towards union membership, the returns to union membership are greater because workers acquire reputational benefits from the purchase. More recently, the experience good model of union membership (see Bryson \& Gomez, 2003; Bryson et al., 2004; Gomez \& Gunderson, 2004) argues that the benefits of union membership, particularly among younger entrants to the labour market, are uncertain and difficult to quantify. The value of joining a union can therefore only be gauged through its direct experience or via the experience and personal recommendations of close associates. Those working in regions of relatively high union density will find it easier to assess the benefits of membership via the positive attitudes to unionization of those around them. In contrast, within regions of low union density if fewer workers experience unionism and see the true benefits, then fewer workers support unions and union density declines. This increases the never unionization rate and creates a self-perpetuating decline in union density (see Booth et al. 2010; Bryson \& Gomez, 2005). Both the 'social custom' and 'experience good' models point towards a path dependence in unionization and industrial relations practices. 
These insights have been confirmed by empirical studies in various related ways. Research has acknowledged the role of social networks in having a positive influence on union joining behaviour (Gomez et al., 2002; Griffin \& Brown, 2011; Haynes et al., 2005). The significance of the family in shaping ideas about trade unionism is also well established (see, for example, Healy \& Kirton, 2013; Klandermans, 1986; Waddington \& Kerr, 2002). The influence of parents on children's commitment to the labour movement has also been demonstrated to be greater among those who participate in union activities (Hester \& Fuller, 2001). Evidence of the importance of socialization within the family is provided by those studies that find increased levels of membership among the children of unionized parents (Visser, 2002). Studies based upon panel data further reveal that the intergenerational transmission of union membership among young workers cannot simply be attributed to cross-generational correlations in the determinants of union membership (including the transmission of political beliefs) and again indicate that the strength of this transmission is stronger where fathers are active in trade unions (Blanden \& Machin, 2003). The strength of intergenerational transmission has also been found to be stronger when both parents are union members and among those born within areas characterized by high union density (Bryson \& Davies, 2019). These studies all support the contention that 'industrial relations traditions of key groups of workers, firms and industries in a region are not self-contained, but rather generate spillovers to other workers, firms and industries in the region through the course of time' (Martin et al., 1996: 118).

\section{3 | THE IMPORTANCE OF MINING}

\section{1 | Employment and the organization of labour}

Mining has always been a relatively small part of the overall UK economy but quite fundamental to it. The height of employment within coalmining in the United Kingdom was during the period 1913-1922 (see Table 1). During this decade, on average approximately one million people were employed in the sector, representing a little over 5 per cent of those in employment. Employment in mining actually peaked at 1.19 million in 1920, while employment share was highest during 1923 and 1924 at 6.4 per cent. Employment within the sector declined steadily thereafter, falling to approximately 700,000 in 1947 when the industry was nationalized. The rate of decline in employment increased during the 1960s as the National Coal Board closed less productive pits in peripheral coalfields, including South Wales, Durham, Lancashire and Scotland, as it sought to shift the focus of its production to the low-cost central coalfields located primarily within the East Midlands (Rees, 1985). While the rate of decline fell during the 1970s, by 1979 employment had fallen to 240,000 . Following the $1984 / 1985$ miner's strike, employment in mining had fallen to below 100,000. The most recent data place employment within United Kingdom coalmining at below a 1,000 (BEIS, 2019).

Despite the relatively small size of the sector, mining was a very important source of employment within some areas. Across many parts of the United Kingdom, miners often lived in small, isolated communities within rural environments that they dominated. Regional data from the 1921 Census reveal that 35 per cent of working males (aged 12 or over) resident within the industrial areas of South Wales were employed in mining. Within England, employment within coalmining was also important within the counties of Durham (29 per cent), Derbyshire (24 per cent), Nottinghamshire (21 per cent) and Northumbria (20 per cent). However, examination of data for Local Government Districts reveal the true importance of mining within particular 
TABLE 1 Production and employment within UK coalmining

\begin{tabular}{|c|c|c|c|}
\hline Year & $\begin{array}{l}\text { Total output } \\
\text { (Million tonnes) }\end{array}$ & $\begin{array}{l}\text { Employment } \\
\text { (Thousands) }\end{array}$ & $\begin{array}{l}\text { \% Employed } \\
\text { population }\end{array}$ \\
\hline 1873-1882 & 140.3 & 467 & $3.6 \%$ \\
\hline 1883-1892 & 172.6 & 536 & $3.7 \%$ \\
\hline 1893-1902 & 206.6 & 692 & $4.3 \%$ \\
\hline 1903-1912 & 258.0 & 908 & $5.2 \%$ \\
\hline 1913-1922 & 245.0 & 1036 & $5.4 \%$ \\
\hline 1923-1932 & 236.9 & 975 & $5.2 \%$ \\
\hline 1933-1942 & 224.7 & 749 & $3.5 \%$ \\
\hline 1943-1952 & 208.0 & 704 & $3.0 \%$ \\
\hline 1953-1962 & 215.9 & 664 & $2.7 \%$ \\
\hline 1963-1972 & 170.1 & 378 & $1.5 \%$ \\
\hline 1973-1982 & 124.5 & 231 & $0.9 \%$ \\
\hline 1983-1992 & 95.3 & 81 & $0.3 \%$ \\
\hline 1993-2002 & 44.1 & 11 & $0.0 \%$ \\
\hline 2003-2012 & 19.9 & 6 & $0.0 \%$ \\
\hline
\end{tabular}

Source: BEIS (2019).

localities. For example, in the North East of England, within both the mining districts of Easington in Country Durham and Ashington in Northumberland approximately three quarters of males were employed in mining. Such figures were replicated across many districts of South Wales, including Nantyglo/Blaina (77 per cent); Rhondda (74 per cent); MynyddIslwyn (74 per cent) and Abertillery (73 per cent). In the Midlands, 70 per cent of males living in Bolsover in Derbyshire and Huthwaite in Nottinghamshire worked in mining. Mining defined the very character of these and many other coalfield communities.

The mining workforce was highly unionized. No other unskilled group was able to organize so early and with such completeness as the miners did (Beynon \& Austrin, 1994: 365). The Miners' Federation of Great Britain was formed from a collection of county-based unions in 1888. At its peak in 1920, the constituent federations had approximately 945,000 members (see Marsh \& Ryan, 1984, 198-99), equivalent to approximately 80 per cent of the mining workforce. The intense association between mining and the communities in which it was situated was reflected in both the character of the union movement and the nature of its organization, based as it was upon the local lodge. Within the lodge both industrial and community issues were discussed and in this way mining unionism extended directly into medical, welfare and educational issues. So much so that the miners' libraries in South Wales have been described as the 'greatest network of cultural institutions created by working people anywhere in the world' (Rose, 2001: 237). In these ways and others, [t]he history of mining unionism differed greatly from that of other occupational groups... county-based unions were almost unique to that sector. Still smaller scale localism characterised mining unionism in South Wales, where the Miners' Federation...consisted of 20 districts, corresponding to individual valleys... The union itself became the major cohesive force in the regional formation, dominating all other community institutions from the chapel to the sports team' (Southall, 1988: 480). Traditions of industrial relations were reproduced through such processes of local institutionalization and socialization (Martin et al., 1996). 


\section{2 | Sectoral links and spillovers}

Until the 1960s, the United Kingdom was basically a single fuel economy with electricity generation, transport, steel and chemical production and domestic heating all reliant upon coal. This led to highly significant industrial and trade union interlinks. However, coal is not a uniform commodity. It was in the coking coal areas — notably South Wales, Durham and Lanarkshire - that these connections were most strongly developed and clearly demonstrated in the Triple Alliance of trade unions formed by the coal miners, and the steel and rail workers. In no small part, this development related to the ways in which private employers had formed coal combines that extended across the coal supply chain. These were notable in South Wales (Williams, 1995) but also in the North East where the Dorman Long company operated steel mills on Teesside as well as owning eight coking coal pits in Durham with directors on the boards of others. In its assessment in 1939 Labour Research concluded that 'It would be difficult to find a closer link between coal, by products and all branches of the iron and steel industry than is represented by this well-knit Durham combine' (Labour Research Department, 1939: 6). In these areas, trade unionism developed along this chain with each of the occupations developing their own distinctive structures and forms of organizing, often in cooperation with each other.

The coal districts suffered severely during the economic depression of the 1930s. When Pilgrim's Trust researchers visited Crook in Durham in 1936, they recorded that 71 per cent of unemployed miners had been out of work for over five years. In Merthyr Tydfil and the Rhondda valley, similar findings were made. Overall, they found that 123 in every 1,000 coalminers had been out of work for over a year, a figure that contrasted remarkably with that for new industries like car manufacture (Pilgrims Trust, 1938). During this time, the coalfields became identified as the 'distressed areas' and, in small part, a source of labour supply for these new industries. Unemployed miners from South Wales travelled to Oxford to work for Morris Motors forming Williams' second generation (Williams, 1964). In Durham too, significant numbers of miners moved to work for the developing Imperial Chemical Industries (ICI) company on Teesside. As one of the local managers put it 'There was a lot of very good labour in the Durham coalfield and they flocked down to Teesside' (Pettigrew, 1985: 126). These ex-miners would have been members of the Durham Miners Association. Many would have come from South West Durham where their experiences of the paternalistic practices of companies like Pease and Partners (Emery, 1984) would have prepared them for the kind of industrial relations being developed at the Billingham ICI plant.

The election of a Labour government in 1945 and the subsequent nationalization of the industry secured both an essential resource at a time of reconstruction and the future of the newly formed NUM, which was included in the Act that made the National Coal Board a closed shop of 700,000 employees. Alongside this, a programme of social investment underpinned and secured the stability of the local mining population in their communities for a decade and a half. However, changes in the energy markets undermined these arrangements. Oil from the Middle East ended the dominance of coal and in the twelve years between 1958 and 1970 many mines were closed especially in South Wales, Durham and Scotland. Miners from these areas were relocated to other pits in the midlands but most $(400,000)$ left the industry, some into retirement, many into the branch plants of the new manufacturing industries. In Durham, much of this investment took place along transport routes that were within the boundary of the old coalfield with Nissan the most prominent example. In South Wales, similar location decisions were made with Ford and Bosch, although these plants were located beyond the southern boundary of the old coalfield (Beynon \& Hudson, 2021). While there have been no systematic studies of the impact of this relocation of labour upon 
trade union density, there are anecdotal and biographical accounts of miners carrying their trade union involvement into the new factories (Beavis, 1980).

\subsection{Collective action and narrative resources}

Energy markets changed again and encouraged by the increase in the price of oil imports, the NUM called a highly successful national strike in 1972 and another in 1974 that was attributed with bringing down the Heath government. These strikes re-established the coal miners and the NUM to a central position within the UK trade union movement. The year-long strike in 1984, while more controversial, also had a powerful impact. It drew attention to the retained strength of the local communities in the mining areas (Griffiths \& Johnston, 1991; Samuel et al., 1986; Sunley, 1990). The fact that almost all the mines subsequently closed within 10 years of the strike ending proved convincing evidence of the justice of their struggle and in the old coalmining areas the strike continues to have an ongoing, active, symbolic presence, which shapes present day attitudes towards trade unionism (Beynon, 2014). Low levels of both inward and outward migration (ONS 2016) also mean that these communities are characterized by a resident population who remain more closely connected to the experience of the strike through the ties of family, friends and place. These experiences contribute to the 'narrative resources' that have been identified as important for union renewal - 'the range of values, shared understandings, stories and ideologies that aggregate identities and interests and translate and inform motives' (Levesque \& Murray, 2010: 339). These shared values and experiences relate to the 'structure of feeling' (Williams, 1961) within coalmining areas that supports a continued commitment to trade unionism.

\section{4 | DATA}

The main source of data regarding union membership within the United Kingdom is the LFS. Interviews are conducted quarterly in approximately 40,000 households, with information being collected for around 100,000 individuals. Households remain in the LFS for up to five successive quarters (referred to as Waves), although they are not followed up if they change address. Questions on trade union membership are included in the fourth calendar quarter and are asked of all those in employment. Respondents are firstly asked 'Are you a member of a trade union or staff association?'. The ability to become a union member will reflect the opportunity to join. Within the LFS, the presence of trade unions at a workplace is therefore also established with a follow-up question which asks non-members whether any other people at their workplace are members of a trade union or staff association. By restricting the LFS sample to those who are employed in workplaces where unions are present, spatial variance in the opportunity to join a union can be accounted for.

Although a large survey, sample sizes still limit the ability of the LFS to provide detailed information about geographical variations in union membership during any given year. Published estimates of union membership within the United Kingdom are therefore only provided for relatively broad geographical areas. To produce small area estimates of union membership, we combine data covering the period from 2000 to 2018, reflecting the availability of consistent geographical identifiers. Due to our interest in examining the effect of living in old coalmining areas on the likelihood of being a union member, all analyses are based upon place of residence as opposed to place of work. Those who are self-employed are excluded from the analysis, reflecting the low rate 
of membership (7 per cent) among this group and as is common in the analysis of union density (BEIS, 2020).

To examine how union density varies among those residing in old coalmining areas, we utilize a definition of coalfields developed by Beatty \& Fothergill (1996). Based upon ward-level Census data for 1981, the authors define coalfields as those areas where 10 per cent or more of male residents in employment worked in the coal industry. This was the last Census taken before the major colliery closures that led to the year-long strike by miners in 1984/1985 and the eventual erosion of the industry. It takes a snapshot of that moment of stability between the major rundown of coalmining in the 1960s and the eventual end of mining. In some areas, this statistical threshold was interpreted flexibly, for example to include some wards that did not meet the 10 per cent criteria but which were either largely or wholly surrounded by other coalfield wards or where mining took place in more built up diversified industrial areas where there was slightly lower dependence upon coalmining employment. The definition of coalfields was subsequently expanded to include two additional old coalfields that had already lost their workforce by 1981; Gloucestershire and Cumbria (ICRRDS, 2003). These definitions of coalfields have been central to the provision of data to inform discussions regarding the consequences of industrial decline and what can be done to regenerate these areas (Beatty et al., 2019; Coalfields Task Force, 1998).

The coalfield files are held in the form of look-up tables that list which Lower Layer Super Output Areas (LSOAs) (England and Wales) or Data Zones (Scotland) are located within particular coalfield areas. These Census-based geographies are also available within LFS from 2005 onwards, enabling those respondents who reside within a coalfield area within Great Britain (Northern Ireland is excluded from our analysis) to be flagged. We also consider the importance of geographical spillover by examining how levels of union membership vary with respect to how far away those in employment live from what were once coalmining areas. Distances, measured in kilometres, have been derived from the centroids of all LSOAs and Data Zones within Great Britain to their nearest coalfield boundary. These have been calculated based upon road network travel distances using the Ordinance Survey's MasterMap Highways Network. Again, these distances have been merged onto LFS data on the basis of Census geographies. As such, all those living within an LSOA or Data Zone will either be recorded as residing within a coalfield or will be assumed to live the same distance away from the nearest coalfield.

Finally, in his workplace-level study of the spillover of union membership within the United States, Holmes (2006) restricted his analysis to a selection of non-traded industries within the private sector encompassing construction, wholesale groceries, retail groceries, hotels, nursing homes and hospitals. This group of relatively unorganized sectors was chosen because they were both geographically homogenous and diffuse. To examine whether spillovers in union membership occur among similar sectors within Great Britain, our analysis is undertaken for both all employees and then those employed within Construction; Wholesale and Retail; and Hotels and Restaurants as defined by Sections of the Standard Industrial Classification. To focus upon those in the private sector, our selection of non-traded industries does not include those employed within Health.

\section{5 | DESCRIPTIVE ANALYSIS}

Figure 1 presents population weighted estimates of employee union density for detailed areas of Great Britain for the period 2000-2018. ${ }^{2}$ These areas relate to Unitary Authorities and Local Authority Districts as they were prior to the reorganization of local government in England that 


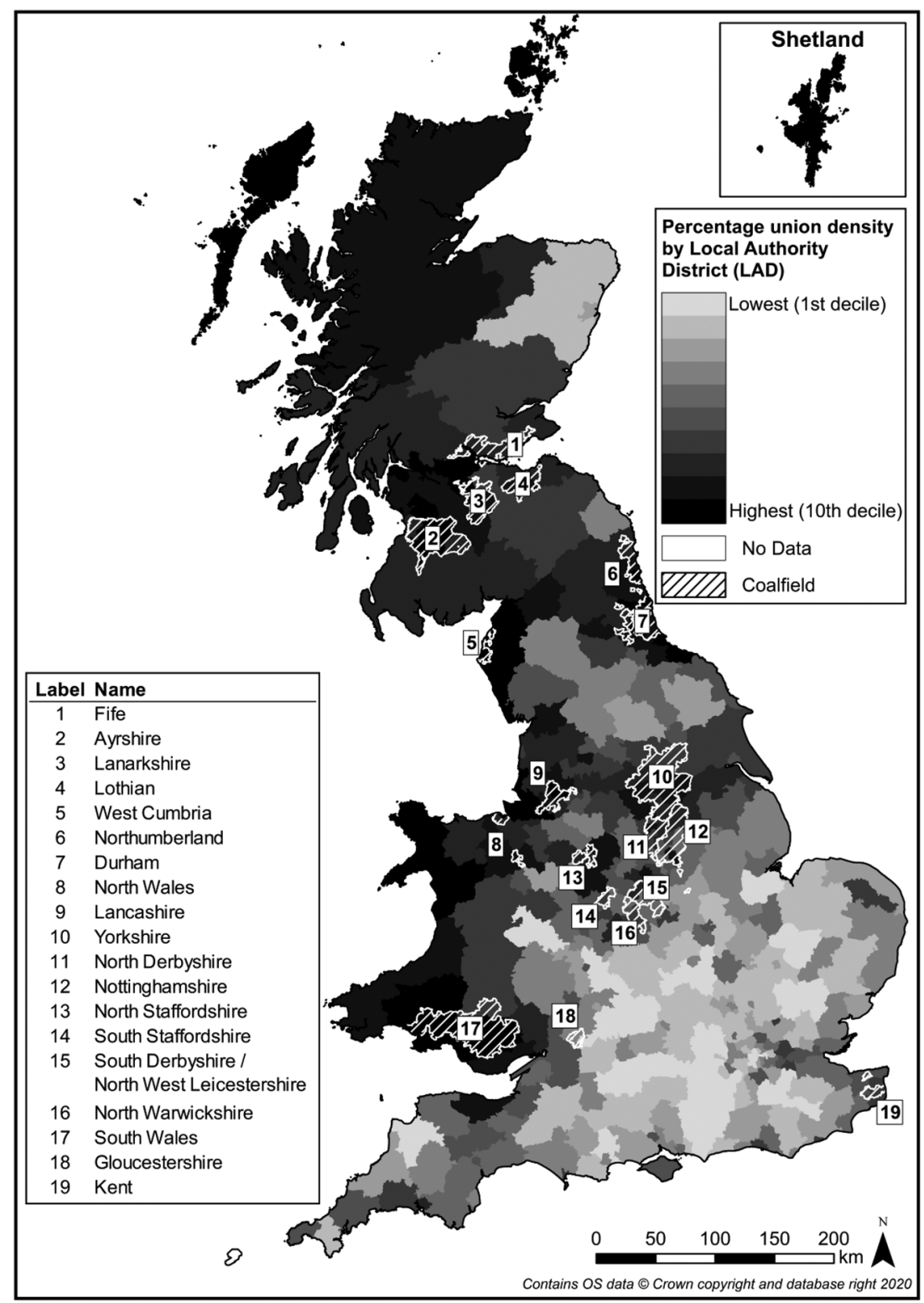

F I G U R E 1 Small area estimates of union density; 2000-2018.

were brought into effect in April 2009. ${ }^{3}$ The shading of the map refers to the position of an area within the overall distribution of union membership, based upon deciles. Coalfield boundaries have also been overlaid. In line with official statistics, union density is lowest within Southern England. Many coalmining areas continue to exhibit relatively high levels of union membership, most notably South Wales and the North East. There are areas beyond the boundaries of these coalfields that also exhibit relatively high levels of union density, such as Merseyside in the North West and Strathclyde in Scotland. The importance of examining union membership at a sub-regional level (Beaumont \& Harris, 1988) is highlighted by the relatively low levels of membership that 
exist within some parts of the country that are generally regarded as having high levels of union membership overall, such as Aberdeenshire in Scotland and North Yorkshire.

Table 2 provides a more direct assessment of the association between union density and residence within a coalmining area. Across Great Britain as a whole, levels of union membership are higher in ex-mining areas (32 per cent) than elsewhere (25 per cent). Within-region comparisons demonstrate that this mining differential is not simply a by-product of mining areas being located within the more unionized parts of Great Britain. For example, within Wales there is a 6 percentage point differential between those residing in ex-mining areas (39 per cent) compared to those living elsewhere (33 per cent). Subject to the caveat of small sample sizes, union density among those living within what was the Kent coalfield $(n=289)$ is 13 percentage points higher than living in the rest of the South East. The Strathclyde region of Scotland is the only part of Great Britain where union density is higher within non-mining areas. The higher levels of density within ex-mining areas can also not simply be attributed to the increased opportunity to join unions. Restricting the sample to those who are employed within unionized workplaces, the propensity to join trade unions remains higher within ex-mining areas (63 per cent) compared to non-mining areas (57 per cent). The increased propensity of workers from coalmining areas to join unions within particular regions also persists upon controlling for spatial variance in union presence.

The effect of coalmining as a source of transmission for union membership would be expected to have spilt over into neighbouring areas through the course of time. Table 3 demonstrates that union density declines steadily with respect to how far away those in employment live from the boundary of a coalfield. Those who live furthest away from old coalmining areas will of course capture those residing in regions that are distant from old mining areas and where union density is generally low, such as the South East, the South West and Eastern England. However, union density is lower even among those who reside just several kilometres away from the boundaries of ex-mining areas. In accordance with Holmes (2006), Table 3 also considers how the influence of coalmining has spilt over to those in relatively unorganized sectors. Among our selection of nontraded sectors (construction; wholesale and retail and hotels and restaurants), the rate of union membership is much lower than that which is observed elsewhere in the economy (11 per cent compared to 31 per cent). However, even within these sectors, union density is higher among those who live within or near old coalmining areas. These patterns also persist among those workers who are employed at workplaces where unions are present, suggesting that the propensity to join unions within these unorganized sectors also diminishes with respect distance from the boundary of a coalfield.

\section{6 | MULTIVARIATE ANALYSIS}

\section{1 | Methodological approach}

The higher levels of union density within areas once characterized by coalmining suggest the importance of industrial heritage in encouraging trade union membership among present day workers. However, these patterns could also be a by-product of geographical differences in the characteristics of individuals, the jobs that they hold or the workplaces in which they are employed. For example, high levels of union membership in Cumbria will in part relate to the highly unionized nuclear workforce that remains in this area. Those employed at the Port of Dover may also contribute to the continued persistence of trade union membership within what was the 
TA B LE 2 Employment and union density in mining and non-mining areas

\begin{tabular}{|c|c|c|c|c|c|c|}
\hline & Union d & nsity & $\begin{array}{l}\text { Union } n \\
\text { where } p\end{array}$ & $\begin{array}{l}\text { mbership } \\
\text { sent }\end{array}$ & \% Empl & edpopulation \\
\hline & Mining & Non-mining & Mining & Non-mining & Mining & Non-mining \\
\hline North East & 34.0 & 32.3 & 63.7 & 61.7 & 28.9 & 71.1 \\
\hline Durham & 33.8 & & 63.6 & & 23.5 & \\
\hline Northumberland & 34.9 & & 64.2 & & 5.4 & \\
\hline North West & 34.2 & 30.4 & 65.2 & 62.0 & 9.4 & 90.7 \\
\hline Lancashire & 32.6 & & 63.6 & & 8.5 & \\
\hline Cumbria & 49.0 & & 78.4 & & 0.9 & \\
\hline Yorkshire & 30.8 & 27.4 & 60.7 & 57.6 & 23.5 & 76.5 \\
\hline Yorkshire & 30.8 & & 60.7 & & 23.5 & \\
\hline East Midlands & 28.3 & 23.8 & 59.6 & 54.1 & 22.4 & 77.6 \\
\hline Derby & 29.3 & & 58.9 & & 7.1 & \\
\hline $\begin{array}{l}\text { South Derbyshire } \\
\text { /North West } \\
\text { Leicestershire }\end{array}$ & 27.3 & & 61.3 & & 3.9 & \\
\hline Nottinghamshire & 28.0 & & 63.9 & & 11.4 & \\
\hline West Midlands & 28.1 & 25.5 & 61.4 & 57.9 & 10.8 & 89.2 \\
\hline Warwickshire & 25.5 & & 57.9 & & 3.7 & \\
\hline South Staffordshire & 26.6 & & 61.3 & & 2.4 & \\
\hline North Staffordshire & 30.8 & & 63.9 & & 4.8 & \\
\hline East of England & & 21.4 & & 54.0 & & 100.0 \\
\hline London & & 20.8 & & 55.5 & & 100.0 \\
\hline South East & 33.8 & 20.3 & 62.3 & 52.4 & 0.4 & 99.6 \\
\hline Kent & 33.8 & & 62.3 & & 0.4 & \\
\hline South West & 26.8 & 23.5 & 60.0 & 53.5 & 0.7 & 99.3 \\
\hline Forest of Dean & 26.8 & & 60.0 & & 0.7 & \\
\hline Wales & 39.2 & 33.1 & 69.6 & 63.0 & 25.2 & 74.8 \\
\hline North Wales & 35.0 & & 71.6 & & 0.6 & \\
\hline South Wales & 39.3 & & 69.6 & & 24.6 & \\
\hline $\begin{array}{l}\text { Scotland: } \\
\text { Strathclyde }\end{array}$ & 31.1 & 34.4 & 63.2 & 66.3 & 5.9 & 94.1 \\
\hline Ayrshire & 31.7 & & 64.4 & & 2.7 & \\
\hline Lanarkshire & 30.5 & & 62.2 & & 3.2 & \\
\hline Rest of Scotland & 31.6 & 28.9 & 61.0 & 60.1 & 13.2 & 86.8 \\
\hline Fife/Central & 31.3 & & 60.7 & & 8.5 & \\
\hline Lothian & 32.1 & & 61.6 & & 4.7 & \\
\hline All & 32.0 & 25.0 & 62.9 & 57.2 & 9.6 & 90.4 \\
\hline Sample & 44,273 & 414,821 & 23,023 & 186,879 & 44,273 & 414,821 \\
\hline
\end{tabular}

Note: Derived from Labour Force Survey, 2005-2018. Data are weighted. 
TA B LE 3 Geographical spillover of union density

\begin{tabular}{|c|c|c|c|c|}
\hline \multirow[b]{2}{*}{ Distance from coalfield } & \multicolumn{2}{|l|}{ Union density } & \multicolumn{2}{|c|}{$\begin{array}{l}\text { Membership where unions are } \\
\text { present }\end{array}$} \\
\hline & All employees & $\begin{array}{l}\text { Selected } \\
\text { non-traded } \\
\text { sectors }\end{array}$ & All employees & $\begin{array}{l}\text { Selected } \\
\text { non-traded } \\
\text { sectors }\end{array}$ \\
\hline 0 km (within Coalfield) & 32.0 & 14.5 & 62.9 & 50.3 \\
\hline $0 / 5 \mathrm{~km}$ & 31.2 & 13.4 & 61.4 & 48.6 \\
\hline $5 / 10 \mathrm{~km}$ & 29.1 & 11.7 & 59.4 & 46.8 \\
\hline $10 / 20 \mathrm{~km}$ & 28.4 & 11.8 & 59.7 & 46.9 \\
\hline $20 / 50 \mathrm{~km}$ & 27.1 & 11.4 & 58.2 & 46.7 \\
\hline $50 / 100 \mathrm{~km}$ & 22.5 & 9.0 & 55.6 & 42.1 \\
\hline $100+\mathrm{km}$ & 21.1 & 8.5 & 54.0 & 43.1 \\
\hline All & 25.6 & 10.7 & 57.8 & 45.7 \\
\hline Sample & 458,865 & 110,996 & 209,842 & 26,715 \\
\hline
\end{tabular}

Note: See Table 2.

Kent Coalfield in South East England. To take account of such confounding factors, we estimate a series of multivariate logistic regressions that model the probability of union membership among our sample of respondents to the LFS. Models of the following general form are estimated:

$$
M E M_{i t}=\alpha+P C_{i t} \beta+J O B_{i t} \gamma+R E S P_{i t} \pi+R E G_{i} \delta+C O A L_{i} \lambda+\varepsilon_{i t}
$$

The analysis is based upon pooled individual level data from the LFS covering the period 20052018. The dependent variable $M E M_{i t}$ identifies whether an employee $i$ is a member of a union during year $t$. Our key explanatory variables of interest are those that identify whether employees live either within or near an old coalmining area $\left(C O A L_{i}\right)$. To isolate the separate effect of living in a coalmining area on the likelihood of being a trade union member, the model conditions on a range of variables to control for characteristics commonly associated with trade union membership (see Annex 1 for details). For personal characteristics $\left(P C_{i t}\right)$, we simply control for age and gender. In terms of job-related characteristics $\left(J O B_{i t}\right)$, we control for key determinants of union membership including occupation, industry, sector of employment, hours worked and workplace size. Respondent characteristics $\left(R E S P_{i t}\right)$ include variables to control for year of response; the mode of survey delivery (telephone or face-to-face interview); and whether the interview was conducted with a proxy respondent since they are known to underreport union membership within the LFS (BIS, 2013). Finally, the inclusion of control variables for region of residence $\left(R E G_{i}\right)$ allows us to account for otherwise unobserved characteristics that may vary by region enabling us to evaluate whether coalmining areas remain a focal point for union membership compared to the localities that surround them.

The analysis is conducted broadly in three stages. First, we examine whether those employees who live beyond the boundaries of an old coalmining area are less likely to be members of a trade union. This is captured through the inclusion within our logistic regressions of a dummy variable that distinguishes those employees who reside within old coalmining areas $(=0)$ as opposed to those who live elsewhere $(=1)$. The second stage considers the issue of geographical spillover. The dichotomous coalfield variable used in stage 1 is replaced with a set of mutually exclusive dummy variables that group employees based on how far away they live from the boundary of 
their nearest coalfield. Stages 1 and 2 both derive GB-level estimates which constrain the effect of coalmining areas on union membership to be uniform across Great Britain. This restriction however may not be appropriate. First, there are well-documented differences in attitudes towards collective action between coalfields (Griffiths \& Johnston, 1991; Sunley, 1990). Second, depending upon their location, the 'coalfield effect' may be dampened or enhanced by proximity to other industries that also developed their own local traditions for union membership. The third stage of our analysis therefore presents regional specific estimates of the 'coalfield effect' through the inclusion of variables that distinguish residence in relation to coalmining areas separately for those living within different parts of Great Britain.

Within each stage, our analyses are first conducted for all employees. We then restrict our sample to those workers who are employed at unionized workplaces to account for geographical variance in the opportunity to join unions. We also examine whether a 'coalfield effect' can be identified among those employed within selected industries from the non-traded sector. The results from our logistic regressions are expressed in terms of odds ratios which are derived by taking the exponential of the estimated regression coefficients. An odds ratio significantly higher (lower) than one indicates a higher (lower) odds of being a union member compared to the reference group. Those who live in old mining areas are the reference category against whom the effect of living beyond the boundaries of a coalfield is appraised. Within all regressions, assessments of statistical significance are based upon robust standard errors that account for repeated observations from those individuals who may have responded to questions on union membership in both Wave 1 and Wave 5 of the LFS.

\section{\begin{tabular}{l|l}
7 & RESULTS
\end{tabular}}

Table 4 presents multivariate estimates of the effects of residing in coalmining areas derived from logistic regressions as described above, expressed as odds ratios. The first panel reveals that across Great Britain as a whole, living within a non-mining area (Model 1, Column 1) significantly reduces the likelihood of union membership (odds ratio of 0.807) compared to those living within the boundaries of old mining areas. Those living beyond the boundaries of coalmining areas are 0.8 times as likely (or alternatively 20 per cent less likely) to be members of a trade union than those who live within. The effect of living outside a coalfield upon union membership persists upon restricting the sample to those employed within workplaces where unions are present (Model 1, Column 2 - odds ratio of 0.835).

The second panel of Table 4 considers how the probability of union membership varies according to the distance lived from a coalmining area. Declining odds ratios with respect to distance (Model 2, Column 1) indicate that the probability of union membership declines among those who live further away from the boundary of an old mining area. The largest step reduction in the probability of union membership with respect to distance however is observed among those who live only just beyond the boundaries of old mining areas. Those living less than $5 \mathrm{~km}$ away from the boundaries of old coalmining areas are estimated to be 11 per cent less likely to be a member of a trade union than those living within (odds ratio of 0.891). The rate of decline reduces thereafter. The reduced likelihood of being a member of trade union increases to 16 per cent (odds ratio of 0.843 ) among those residing 5-10 km away from a coalfield boundary and to 21 per cent (odds ratio of 0.785 ) among those living 10-20 km away. This pattern persists when we restrict the sample to those employed in workplaces where unions are present (Model 2, Column 2), although the estimated effects of distance are dampened slightly for those living furthest away from coalfield 
TA B L E 4 Odds of Union Membership: GB level estimates of coalfield effects

\begin{tabular}{|c|c|c|}
\hline & All employees & Where unions present \\
\hline \multicolumn{3}{|l|}{ All Sectors } \\
\hline \multicolumn{3}{|l|}{ Model 1} \\
\hline Mining areas & ref. $(=1)$ & ref. $(=1)$ \\
\hline Non-mining areas & $0.807^{* * *}$ & $0.835^{* * *}$ \\
\hline$R^{2}$ & 0.28 & 0.13 \\
\hline Sample & 455,925 & 209,055 \\
\hline \multicolumn{3}{|l|}{ Model 2} \\
\hline Mining areas & ref. & ref. \\
\hline $0 / 5 \mathrm{~km}$ & $0.891^{* * *}$ & $0.900^{* * *}$ \\
\hline $5 / 10 \mathrm{~km}$ & $0.843^{* * *}$ & $0.862^{* * *}$ \\
\hline $10 / 20 \mathrm{~km}$ & $0.785^{* * *}$ & $0.819^{* * *}$ \\
\hline $20 / 50 \mathrm{~km}$ & $0.780^{* * *}$ & $0.796^{* * *}$ \\
\hline $50 / 100 \mathrm{~km}$ & $0.726^{* * *}$ & $0.794^{* * *}$ \\
\hline $100+\mathrm{km}$ & $0.680^{* * *}$ & $0.750^{* * *}$ \\
\hline$R$-squared & 0.28 & 0.13 \\
\hline Sample & 455,917 & 209,052 \\
\hline \multicolumn{3}{|c|}{ Selected non-traded sectors } \\
\hline \multicolumn{3}{|l|}{ Model 3} \\
\hline Mining areas & ref. & ref. \\
\hline Non-mining & $0.848^{* * *}$ & $0.895^{* *}$ \\
\hline$R$-squared & 0.17 & 0.08 \\
\hline Sample & 110,073 & 26,575 \\
\hline \multicolumn{3}{|l|}{ Model 4} \\
\hline Mining & ref. & ref. \\
\hline $0 / 5 \mathrm{~km}$ & $0.906^{* *}$ & 0.936 \\
\hline $5 / 10 \mathrm{~km}$ & $0.856^{* * *}$ & 0.910 \\
\hline $10 / 20 \mathrm{~km}$ & $0.840^{* * *}$ & $0.868^{* *}$ \\
\hline $20 / 50 \mathrm{~km}$ & $0.862^{* * *}$ & $0.907^{*}$ \\
\hline $50 / 100 \mathrm{~km}$ & $0.736^{* * *}$ & $0.820^{* * *}$ \\
\hline $100+\mathrm{km}$ & $0.733^{* * *}$ & $0.874^{* *}$ \\
\hline$R^{2}$ & 0.17 & 0.08 \\
\hline Sample & 110,073 & 26,575 \\
\hline
\end{tabular}

Note: Odds ratios are estimated from a logistic regression of union membership $\left(M E M_{i t}\right)$ that include controls for personal, job, workplace and survey characteristics. See text and Annex 1 for a description of control variables.

${ }^{*},{ }^{* *},{ }^{* * *}$ indicate significance at the 10,5 and 1 per cent level, respectively.

areas. The reduced likelihood of union membership as one moves further beyond the boundaries of old coalmining areas can therefore not simply be attributed to the reduced opportunity to join a trade union.

The lower half of Table 4 repeats the analysis for those employed in selected non-traded sectors. It remains the case that living within a non-mining area significantly reduces the likelihood of union membership among employees (Model 3, Column 1 - odds ratio of 0.848 ) and that this 
TA B L E 5 Odds of Union Membership: Regional estimates of the coalfield effect

\begin{tabular}{|c|c|c|c|}
\hline & & All employees & $\begin{array}{l}\text { Where unions } \\
\text { present }\end{array}$ \\
\hline \multirow[t]{2}{*}{ North East } & Mining areas & ref. & ref. \\
\hline & Non-mining areas & 0.951 & 0.927 \\
\hline \multirow[t]{2}{*}{ North West } & Mining areas & ref. & ref. \\
\hline & Non-mining areas & $0.795^{* * *}$ & $0.837^{* * *}$ \\
\hline \multirow{2}{*}{$\begin{array}{l}\text { Yorkshire and } \\
\text { Humberside }\end{array}$} & Mining areas & ref. & ref. \\
\hline & Non-mining areas & $0.805^{* * *}$ & $0.855^{* * *}$ \\
\hline \multirow[t]{2}{*}{ West Midlands } & Mining areas & ref. & ref. \\
\hline & Non-mining areas & $0.721^{* * *}$ & $0.764^{* * *}$ \\
\hline \multirow[t]{2}{*}{ East Midlands } & Mining areas & ref. & ref. \\
\hline & Non-mining areas & $0.793^{* * *}$ & $0.831^{* * *}$ \\
\hline \multirow{2}{*}{ Southern England } & Mining areas & ref. & ref. \\
\hline & Non-mining areas & $0.615^{* * *}$ & $0.779^{*}$ \\
\hline \multirow[t]{2}{*}{ Wales } & Mining areas & ref. & ref. \\
\hline & Non-mining areas & $0.752^{* * *}$ & $0.723^{* * *}$ \\
\hline \multirow[t]{2}{*}{ Strathclyde } & Mining areas & ref. & ref. \\
\hline & Non-mining areas & 1.130 & 1.190 \\
\hline \multirow[t]{2}{*}{ Rest of Scotland } & Mining areas & ref. & ref. \\
\hline & Non-mining areas & $0.866^{* * *}$ & $0.901^{*}$ \\
\hline$R^{2}$ & & 0.28 & 0.13 \\
\hline Sample & & 455,925 & 209,052 \\
\hline
\end{tabular}

Note: See notes to Table 4.

effect persists among those employed at unionized workplaces (Model 3, Column 2 - odds ratio of 0.895). The likelihood of union membership within our selected non-traded sectors declines steadily with respect to distance (Model 4, Column 1). Restricting the analysis to unionized workplaces within selected non-traded sectors does compromise our sample size and contributes to volatility in our distance-based estimates (Model 4, Column 2). Nonetheless, statistically significant evidence of the reduced likelihood of being a union member only emerges among those employees who live further than $10 \mathrm{~km}$ beyond the boundaries of old coalmining areas indicating the weakening effects of geographical spillover with respect to distance.

We next consider whether the 'coalfield effect' varies across different parts of the Great Britain. Due to the small sample sizes associated with some coalfields and the absence of coalmining areas in London and the East of England, this analysis is based around nine broader geographical areas and does not distinguish between the individual coalfields that exist within them. Results of this analysis are presented in Table 5. Across most regions, residing beyond a coalmining area is associated with a significantly lower probability of being a union member compared to other employees residing within the same region (Column 1). Despite the complexities of industrial heritage, the results are relatively uniform. Even where mining took place in more built up diversified industrial areas such as in the West Midlands, the 'coalfield effect' remains (odds ratio of 0.721). The results persist when we restrict our sample to those employed in workplaces where unions are present (Column 2). There are, however, two regions where evidence of a statistically significant differential is absent: the North East and Strathclyde in Scotland. 
Finally, Table 6 examines how the effect of distance lived from a coalmining area upon the likelihood of being a union member varies across different parts of Great Britain. As we are now focusing upon spillover effects within smaller geographical areas, we use $20 \mathrm{~km}+$ to capture those who live furthest away from a coalfield. Across most regions, declining odds ratios again demonstrate that the likelihood of union membership declines with respect to the distance with which employees live away from old mining areas. The reduced sample sizes associated with restricting the analysis to those employed in unionized workplaces both increases the volatility and reduces the statistical significance of the results. Nonetheless, it remains the case that those who live further away from ex-mining areas generally exhibit a reduced likelihood of being a union member. However, evidence of a graduated distance decay in the likelihood of union membership is again absent within Strathclyde and the North East.

Further examination of the small area data for union membership presented in Figure 1 alludes to what is happening in these areas. In Strathclyde, union membership is higher along the River Clyde within the areas of West Dunbartonshire, Renfrewshire and Inverclyde than it is within the old Lanarkshire coalfield. Once characterized by shipbuilding, these areas were another part of the extended production chain from coal and steel that saw the development of skilled trade unionism. Union membership within the contemporary period reflects both some spillover from these industries and from the political activism which, in the early twentieth century, earned it the title 'Red Clydeside'.

In the North East, the patterns are more complex. Those living both 5-10 and 10-20 km away from coalfield areas are estimated to be significantly less likely to be members of trade unions than those who live within (odds ratios of 0.837 and 0.801 , respectively), indicating the continued importance of mining areas as a focal point for union membership within the North East. However, no statistically significant difference in the likelihood of union membership is estimated among those living more than $20 \mathrm{~km}$ away from the boundaries of old mining areas (odds ratio of 1.049). Closer examination of the data reveals that this reflects the high levels of union density observed within the populated areas of Redcar and Cleveland, Stockton on Tees and Middlesbrough which were characterized by employment within other highly unionized sectors including Shipbuilding, Chemicals and Manufacturing (Beynon et al., 1994). Within the steel industry, the increasing need for the importation of vast quantities of iron ore also saw the closure of the steelworks at Consett in Durham in 1980 in favour of the new coastal plant at Redcar. Although apparently distant from the coalfields of the North East, we have noted their historical linksparticularly with steel. The futures of the large coastal coal mines of Blackhall, Horden and Easington up the coast from Hartlepool remained tied to developments on Teesside (Beynon et al., 1991).

Discrepant cases may also relate to issues around the general validity of the coalfield definition we have employed. The emphasis upon residence sits well with the established idea of the colliery village or town with the labour force in residence close to the mine. This was the 'classic' view of coalmining in the United Kingdom and was strongly in evidence in South Wales and Durham. However, the dramatic mine closures that took place in the late 1950s and 1960s affected these arrangements. This was most evident in Durham where, for geological reasons, the newest mines were located to the east of the coalfield where massive collieries were situated along the coast, transporting men to work coal faces under the sea. It was these mines that stayed open for longer, while the smaller older mines in the west around Bishop Auckland, Crook, Spennymoor and Chester-le-Street all closed. In 1981, there were only three small mines-Eden, Bearpark and Sacriston-working on the coalfield west of Durham City with men from the closed mines travelling to the working mines at the coast. Here the general picture is a disruption of the 
TA B LE 6 Odds of Union Membership: Regional estimates of geographical spillover

\begin{tabular}{|c|c|c|c|}
\hline & & All employees & $\begin{array}{l}\text { Where unions } \\
\text { present }\end{array}$ \\
\hline \multirow[t]{5}{*}{ North East } & Mining areas & ref. & ref. \\
\hline & $0-5 \mathrm{~km}$ & 1.015 & 0.989 \\
\hline & $5-10 \mathrm{~km}$ & $0.837^{* * *}$ & $0.791^{* * *}$ \\
\hline & $10-20 \mathrm{~km}$ & $0.801^{* * *}$ & $0.810^{* * *}$ \\
\hline & $20+\mathrm{km}$ & 1.049 & 1.014 \\
\hline \multirow[t]{5}{*}{ North West } & Mining areas & ref. & ref. \\
\hline & $0-5 \mathrm{~km}$ & $0.892^{* *}$ & 0.939 \\
\hline & $5-10 \mathrm{~km}$ & $0.875^{* * *}$ & 0.926 \\
\hline & $10-20 \mathrm{~km}$ & $0.770^{* * *}$ & $0.826^{* * *}$ \\
\hline & $20+\mathrm{km}$ & $0.743^{* * *}$ & $0.768^{* * *}$ \\
\hline \multirow{5}{*}{$\begin{array}{l}\text { Yorkshire and } \\
\text { Humberside }\end{array}$} & Mining areas & ref. & ref. \\
\hline & $0-5 \mathrm{~km}$ & $0.925^{*}$ & 0.966 \\
\hline & $5-10 \mathrm{~km}$ & $0.779^{* * *}$ & $0.853^{* * *}$ \\
\hline & $10-20 \mathrm{~km}$ & $0.805^{* * *}$ & $0.885^{* *}$ \\
\hline & $20+\mathrm{km}$ & $0.763^{* * *}$ & $0.790^{* * *}$ \\
\hline \multirow[t]{5}{*}{ West Midlands } & Mining areas & ref. & ref. \\
\hline & $0-5 \mathrm{~km}$ & $0.754^{* * *}$ & $0.770^{* * *}$ \\
\hline & $5-10 \mathrm{~km}$ & $0.843^{* * *}$ & $0.867^{* *}$ \\
\hline & $10-20 \mathrm{~km}$ & $0.753^{* * *}$ & $0.782^{* * *}$ \\
\hline & $20+\mathrm{km}$ & $0.642^{* * *}$ & $0.701^{* * *}$ \\
\hline \multirow[t]{5}{*}{ East Midlands } & Mining areas & ref. & ref. \\
\hline & $0-5 \mathrm{~km}$ & $0.898^{*}$ & $0.861^{* *}$ \\
\hline & $5-10 \mathrm{~km}$ & $0.867^{* *}$ & $0.873^{* *}$ \\
\hline & $10-20 \mathrm{~km}$ & $0.829^{* * *}$ & $0.879^{* *}$ \\
\hline & $20+\mathrm{km}$ & $0.735^{* * *}$ & $0.791^{* * *}$ \\
\hline \multirow[t]{5}{*}{ Southern England } & Mining areas & ref. & ref. \\
\hline & $0-5 \mathrm{~km}$ & $0.729^{* *}$ & 0.981 \\
\hline & $5-10 \mathrm{~km}$ & $0.721^{* *}$ & 0.822 \\
\hline & $10-20 \mathrm{~km}$ & $0.665^{* * *}$ & $0.773^{*}$ \\
\hline & $20+\mathrm{km}$ & $0.613^{* * *}$ & $0.778^{*}$ \\
\hline \multirow[t]{5}{*}{ Wales } & Mining areas & ref. & ref. \\
\hline & $0-5 \mathrm{~km}$ & $0.821^{* * *}$ & $0.789^{* * *}$ \\
\hline & $5-10 \mathrm{~km}$ & $0.734^{* * *}$ & $0.679^{* * *}$ \\
\hline & $10-20 \mathrm{~km}$ & $0.715^{* * *}$ & $0.682^{* * *}$ \\
\hline & $20+\mathrm{km}$ & $0.718^{* * *}$ & $0.725^{* * *}$ \\
\hline \multirow[t]{5}{*}{ Strathclyde } & Mining areas & ref. & ref. \\
\hline & $0-5 \mathrm{~km}$ & 1.176 & 1.191 \\
\hline & 5-10 km & $1.210^{*}$ & $1.329^{* *}$ \\
\hline & $10-20 \mathrm{~km}$ & 1.050 & 1.126 \\
\hline & $20+\mathrm{km}$ & 1.146 & 1.196 \\
\hline
\end{tabular}


TABLE 6 (Continued)

\begin{tabular}{llll} 
& & All employees & $\begin{array}{l}\text { Where unions } \\
\text { present }\end{array}$ \\
Rest of Scotland & Mining areas & ref. & ref. \\
& $0-5 \mathrm{~km}$ & 0.976 & 0.974 \\
$5-10 \mathrm{~km}$ & 0.909 & 0.959 \\
& $10-20 \mathrm{~km}$ & $0.691^{* * *}$ & $0.653^{* * *}$ \\
$R^{2}$ & $20+\mathrm{km}$ & $0.834^{* * *}$ & $0.888^{*}$ \\
Sample & & 0.28 & 0.13 \\
\hline
\end{tabular}

Note: See notes to Table 4.

established arrangement of the mining village with a concentration of employment along the east coast with a noticeable build-up of miners living in the centre and west of the county travelling quite long distances to their new mines and a possible remoteness from the activities of the union lodge.

A similar though less dramatic effect took place in Scotland where there was also a closure of village pits accompanied by commuting to a limited number of 'cosmopolitan' pits, so called because 'they drew workers from quite widely dispersed localities with distinct political and working cultures' (Phillips, 2012: 258). This contrasts markedly with South Wales where, although the coalfield was similarly diminished, the coal mines (and mining jobs) that remained were spread more evenly from east to west. While the anthracite area in the west was particularly badly hit in terms of mine closures, what remained was a spread of mines across each of the valleys with clusters of dense employment built up around Abertillery, Mountain Ash, Maesteg and Ystradgynlais. Using the 10 per cent residency definition produces a coalfield boundary in South Wales that is very similar to the one drawn around the location of jobs or employment. However, in Durham the boundary based on coal mines (and active lodges) in 1981 would be much more tightly delineated than one based on residence.

\section{CONCLUSIONS}

The analysis demonstrates the persistence of geographical variance in the likelihood of being a union member, linking these patterns to differences in the location of industries characterized by relatively high levels of organized labour. Through the course of time, the effects of these industries on union joining behaviour has spilled over to other sectors of the economy and to neighbouring geographical areas, contributing to regional differences in the likelihood of being a union member. Nonetheless, within these regions it remains the case that those living within areas that were once characterized by coalmining still exhibit an increased likelihood of being a union member compared to those living elsewhere. Current rates of unionization are strongly linked to historical rates of unionization via the 'long shadow' caste by industries, which while no longer present, incubated high levels of union experience in their hey-day.

The influence of family, friends and colleagues on union joining behaviour is empirically well established. It is therefore perhaps not surprising that ex-mining areas, with their relatively settled communities, are places where the importance of such influences will be heightened. What 
is surprising is that the effect of living near these areas on union joining behaviour diminishes so sharply with respect to distance. Union joining probabilities are significantly lower among those who live just a few kilometres beyond the boundaries of these old coalfields. This is not to suggest that the effects of union membership within the coal industry have not spilled over to neighbouring areas over the course of generations. Rather, our analysis demonstrates that coalmining is not the only source of transmission for union membership. Understanding spatial variance in trade union membership requires a detailed geographical analysis at the sub-regional level. Nonetheless, despite the complexities of industrial heritage, mining areas across Great Britain remain important conduits for trade union membership, long after employment within the sector has vanished. This effect is even observed within smaller coalfields in Southern England where union membership is traditionally low. It remains to be seen what might be the 'coalfields' of the future, capable of acting as incubators for future generations of trade union members.

\section{O R C I D}

Alex Bryson (iD https://orcid.org/0000-0003-1529-2010

Rhys Davies (D) https://orcid.org/0000-0002-3479-625X

\section{NOTES}

Office for National Statistics, Social Survey Division, Northern Ireland Statistics and Research Agency, Central Survey Unit (2020). Quarterly Labour Force Survey, 1992-2020: Secure Access. [data collection]. 18th Edition. UK Data Service. SN: 6727, http://doi.org/10.5255.UKDA-SN-6727-20.

Underlying data can be accessed at www.wiserd.ac.uk/UnionMaps

Data for the City of London has been combined with the neighbouring City of Westminster due to the small sample sizes associated with those residing in these areas.

\section{ACKNOWLEDGEMENTS}

The ONS Labour Force Survey has been accessed via the Secure Lab at the UK Data Service whose support is gratefully acknowledged. We are also indebted to Christina Beatty and Steve Fothergill from the Centre for Regional, Economic and Social Research at Sheffield Hallam University for kindly providing the definitions of coalfields used in this article and Sam Jones at WISERD, Cardiff University for his assistance in the preparation of the coalfield boundary data. This article is based on work undertaken in relation to the project Trade Unions, Grass Roots Activism and Solidarity, a work package of the WISERD Civil Society Research Programme funded by the ESRC (ES/S012435/1). None of these organizations bears any responsibility for the analysis or interpretations presented here.

\section{Annex 1: Specification of Categorical Explanatory Variables}

$\begin{array}{lc}\text { Personal Characteristics } & \\ \text { Age } & 16-20,21-25,26-30,31-35,36-40,41-45,46-50, \\ & 51-55,56-60,60+\text { years } \\ \text { Gender } & \text { Male, Female } \\ \text { Region } & \text { Government Office Regions or aggregations } \\ & \text { thereof, as defined in Tables } 5 \text { and } 6\end{array}$




\begin{tabular}{|c|c|}
\hline \multicolumn{2}{|c|}{ Personal Characteristics } \\
\hline \multicolumn{2}{|l|}{ Survey Variables } \\
\hline Year of survey & 2005-2018 inclusive \\
\hline Proxy response & $\begin{array}{l}\text { Personal response/face to face, proxy } \\
\text { response/telephone, proxy response/face to } \\
\text { face; proxy response/telephone }\end{array}$ \\
\hline \multicolumn{2}{|c|}{ Job Characteristics (all refer to current main job) } \\
\hline $\begin{array}{l}\text { Total usual weekly } \\
\text { working hours }\end{array}$ & $0-20,20-35,35-40,40-45,45+$ hours \\
\hline Occupation & $\begin{array}{l}82 \text { occupational dummy variables representing the } \\
\text { minor groups (incl. missing) of SOC } 2000\end{array}$ \\
\hline Industry & $\begin{array}{l}16 \text { dummy variables relating to the Sections (incl. } \\
\text { missing) of SIC92 or aggregations there of }\end{array}$ \\
\hline Sector & $\begin{array}{l}\text { Private sector, nationalized industry, central } \\
\text { government, local government, other }\end{array}$ \\
\hline $\begin{array}{l}\text { Number of employees at } \\
\text { workplace }\end{array}$ & $\begin{array}{l}1-10,11-19,20-24 \text {, do not know but under } 25 \text {, } \\
25-49,50-500,500 \text { or more }\end{array}$ \\
\hline
\end{tabular}

\section{REFEREN CES}

Bain, G.S. \& Elias, P. (1985) Trade union membership in Great Britain: an individual-level analysis. British Journal of Industrial Relations, 23 (1), 71-92.

Beatty, C. \& Fothergill, S. (1996) Labour market adjustment in areas of chronic industrial decline: the case of the UK coalfields. Regional Studies, 30 (7), 627-640.

Beatty, C., Fothergill, S. \& Gore, T. (2019) The State of the Coalfields 2019: Economic and Social Conditions in the Former Coalfields of England, Scotland and Wales. Centre for Regional Economic and Social Research, Sheffield Hallam University.

Beaumont, P.B. \& Harris, R.I.D. (1988) Sub-systems of industrial relations: the spatial dimension in Britain. British Journal of Industrial Relations, 26 (3), 397-407.

Beavis, D. (1980) What Price Happiness? My Life from Coal Hewer to Shop Steward. Durham: Strong Words.

Beynon, H. (1973) Working for Ford. London: Allen Lane.

Beynon, H. (2014) "Still Too Much Socialism in Britain": The legacy of Margaret Thatcher. Industrial Relations Journal, 45 (3), 214-233.

Beynon, H. \& Austrin, T. (1994) Masters and Servants: Class and Patronage in the Making of a Labour Organization. The Durham Miners and the English Political Tradition. London: Rivers Oram Press.

Beynon, H., Davies, R. \& Davies, S. (2012) Sources of Variation in Trade Union Membership across the UK: The Case of Wales. Industrial Relations Journal, 43 (3), 200-221.

Beynon, H. \& Hudson, R. (2021) The Shadow of the Mine: Coal and the End of Industrial Britain. London: Verso.

Beynon, H., Hudson, R. \& Sadler, D.. (1991) A Tale of Two Industries: The Contraction of Coal and Steel in the North East of England. Milton Keynes: Open University Press.

Beynon, H., Hudson, R. \& Sadler, D.. (1994) A Place Called Teesside: A Locality in a Global Economy. Edinburgh: Edinburgh University Press.

Blanden, J. \& Machin, S. (2003) Cross-generation correlations of union status for young people in Britain. British Journal of Industrial Relations, 41 (3), 391-415.

Booth, A.L. (1985) The free-rider problem and a social custom model of trade union membership. Quarterly Journal of Economics, 100 (1), 253-261.

Booth, J.E., Budd, J.W. \& Munday, K.M. (2010) 'Never say never? Uncovering the never-unionized in the United States'. British Journal of Industrial Relations, 48 (1), 26-52. 
Bryson, A. \& Blanchflower, B.. (2009) Trade union decline and the economics of the workplace. In W. Brown, A. Bryson, J. Forth and K. Whitfield (eds.), The Evolution of the Modern Workplace. Cambridge: Cambridge University Press.

Bryson, A. \& Davies, R. (2019) Family, place and the intergenerational transmission of union membership. British Journal of Industrial Relations, 57 (3), 624-50.

Bryson, A. \& Forth, J. (2017) The Added Value of Trade Unions. Trades Union Congress. https://www.tuc.org.uk/ added-value-trade-unions

Bryson, A. \& Gomez, R. (2003) Buying into union membership. In H. Gospel and S. Wood (eds.), Representing Workers: Union Recognition and Membership in Britain. London: Routledge.

Bryson, A. \& Gomez, R. (2005) Why have workers stopped joining unions? The rise in never-membership in Britain. British Journal of Industrial Relations, 43 (1), 67-92.

Bryson, A., Gomez, R. \& Willman, P. (2004) The end of the affair? The decline in employers propensity to unionize. In J. Kelly and P. Willman (eds.), Union Organization and Activity. London: Routledge, pp. 129-149.

Bulmer, M.I.A. (1975) Sociological models of the mining community. Sociological Review, 23 (1), 61-92.

Charlwood, A. (2002) Why do non-union employees want to unionize? Evidence from Britain. British Journal of Industrial Relations, 40 (3), 463-491.

Coalfields Task Force (1998) Making the Difference, A New Start for Englands Coalfield Communities. The Coalfields Task Force Report, June.

Department for Business, Energy and Industrial Strategy (2019) Digest of UK Energy Statistics (DUKES) 2019. https://www.gov.uk/government/statistics/digest-of-uk-energy-statistics-dukes-2019

Department for Business, Energy and Industrial Strategy (2020) Trade Union Statistics 2019. www.gov.uk/ government/statistics/trade-union-statistics-2019

Department for Business, Innovation and Industrial Strategy (2013) Measuring Bias in the LFS for Trade Union Membership Statistics. BIS/13/733.

Diamond, W. \& Freeman, R. (2002) What Workers Want from Workplace Organisations: A Report to the TUCs Promoting Trade Unionism Task Group. London: Trades Union Congress.

Dunlop, J.T. (1958) Industrial Relations Systems. New York: Henry Holt.

Elsheikh, F. \& Bain, G.S. (1980) Unionisation in Britain: an inter-establishment analysis based on survey data. British Journal of Industrial Relations, 18 (2), 169-178.

Emery, Norman. (1984) Pease and Partners and the Deerness Valley: Aspects of the Social and Economic History of Waterhouses, Esh Winning and Ushaw Moor, Durham Theses. Durham University. Available at Durham E-Theses Online: http://etheses.dur.ac.uk/7831/

Goldthorpe, J.H., Lockwood, D., Bechhofer, F. \& Platt, J. (1969) The Affluent Worker in the Class Struggle. Cambridge: Cambridge University Press.

Gomez, R. \& Gunderson, M. (2004) The experience good model of trade union membership. In P. V. Wunnava (ed.), The Changing Role of Unions: New Forms of Representation. London: Routledge.

Gomez, R., Gunderson, M. \& Meltz, N. (2002) 'Comparing youth and adult desire for unionization in Canada'. British Journal of Industrial Relations, 40, 521-42.

Green, F. (1992) Recent trends in British trade union density: how much of a compositional effect?. British Journal of Industrial Relations, 30 (3), 445-58.

Griffin, L. \& Brown, M. (2011) Secondhand views? Young people, social networks and positive union attitudes. Labour and Industry: A Journal of the Social and Economic Relations of Work, 22 (1), 83-101.

Griffiths, M. \& Johnston, R.J. (1991) Whats in a place? An approach to the concept of place, as illustrated by the British National Union of Mine-workers' strike, 1984-85. Antipode, 23( 2), 185-213.

Haynes, P., Vowles, J. \& Boxall, P. (2005) Explaining the younger- older worker union density gap: evidence from New Zealand. British Journal of Industrial Relations, 43 (1), 93-116.

Healy, G. \& Kirton, G. (2013) The early mobilization of women union leaders - a comparative perspective. British Journal of Industrial Relations, 51 (4), 709-732.

Hester, K. \& Fuller, B. (2001) Building union commitment: the impact of parental attitudes and participation. Labor Studies Journal, 26 (2), 17-30.

Holmes, T.J. (2006) Geographic Spillover of Unionism. Federal Reserve Bank of Minneapolis Research Department Staff Report 368. 
International Centre for Regional Regeneration \& Development Studies (2003) Updating Coalfield Areas. London: ODPM

Klandermans, B. (1986) Psychology and trade union participation: joining, acting, quitting. Journal of Occupational Psychology, 59 (3), 189-204.

Labour Research Department (1939) Coal Combines in Durham. London: Farleigh.

Lévesque, C. \& Murray, G. (2010) Understanding union power: resources and capabilities for renewing union capacity. Transfer: European Review of Labour and Research, 16 (3), 333-350.

MacKay, R.R. \& Davies, R. (2012) Collective learning, effective demand, loss of work and loss of direction: the growing regional divide within the UK. Regional Studies, 46 (7), 859-871.

Marsh, A. \& Ryan, V. (1984) Historical Directory of Trade Unions, Volume 2. Aldershot: Gower.

Marshall, F.R. (1967) Labor in the South. Cambridge: Harvard University Press.

Martin, R., Sunley, P. \& Wills, J. (1996) Union Retreat and the Regions: The Shrinking Landscape of Organised Labour. London: Jessica Kingsley Publishers Limited.

Monastiriotis, V. (2007) Union retreat and regional economic performance: the UK experience. Regional Studies, $41(2), 143-156$.

Office for National Statistics (2016) Internal Migration, England and Wales: Year Ending June 2015. Statistical Bulletin.

Pettigrew, A. (1985) The Awakening Giant: Continuity and Change in ICI. Oxford: Blackwell.

Phelps Brown, H. (1959) The Growth of British Industrial Relations. London: Macmillan

Phillips, J. (2012) Material and moral resources: the 1984-5 miners' strike in Scotland. Economic History Review, 65 (1), 256-276.

Pilgrims Trust (1938) Men without Work. Cambridge: Cambridge University Press.

Rees, G. (1985) Regional restructuring, class change, and political action: preliminary comments on the 1984-1985 miners strike in South Wales. Environment and Planning D: Society and Space, 3 (4), 389-406.

Rose, J. (2001) The Intellectual Life of the British Working Classes.. New Haven: Yale University Press.

Samuel, R., Bloomfield, B. \& Boanas, G. (1986) The Enemy Within: Pit Villages and the Miners Strike of 1984-5. London: Routledge \& Kegan Paul.

Southall, H. (1988) Towards a geography of unionisation: the spatial organisation and distribution of early British trade unions. Transactions of the Institute of British Geographers, 13 (4), 466-483.

Sunley, P. (1990) Striking parallels: a comparison of the geographies of the 1926 and 1984-85 coalmining disputes. Environment and Planning D: Society and Space, 8 (1), 35-52.

Visser, J. (2002) Why fewer European workers join unions. A social customs explanation of membership trends. British Journal of Industrial Relations, 40 (3), 403-430.

Waddington, J. \& Kerr, A. (2002) Unions fit for young workers?. Industrial Relations Journal, 33 (4), $298-315$.

Williams, J.L. (1995) Was Wales Industrialised?: Essays in Modern Welsh History. Llandysul: Gomer.

Williams, R. (1961) The Long Revolution.. London: Chatto \& Windus.

Williams, R. (1964) Second Generation. London: Chatto and Windus.

How to cite this article: Beynon $\mathrm{H}$, Blakely $\mathrm{H}$, Bryson $\mathrm{A}$, Davies $\mathrm{R}$. The persistence of union membership within the coalfields of Britain. British Journal of Industrial Relations. 2021;1-22. https://doi.org/10.1111/bjir.12588 